\title{
Formulation development of original canned meat and vegetables for healthy nutrition
}

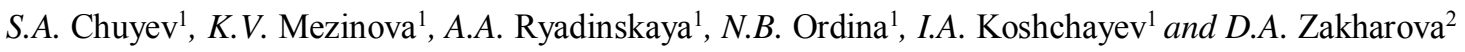 \\ ${ }^{1}$ Belgorod GAU, Maysky settlement, Russian Federation \\ ${ }^{2}$ Administration of the Governor of Belgorod Region, Belgorod, Russian Federation
}

\begin{abstract}
The article pays attention to the problem of creating balanced products based on poultry meat and plant raw materials, which can make the nutrition of modern man more rational, restore and maintain metabolic processes, and increase body's resistance to the effects of adverse life factors. Results of a research on development of formula model of original canned meat and vegetables food for healthy nutrition are given. Quality indicators of product samples are determined: food and energy value, its mineral and vitamin composition. It has been shown that joint and separate inclusion of beans, pumpkin, and Brussels cabbage as a plant ingredient in production technology of meat and vegetable chunks based on chicken meat allows to satisfy daily human need for protein by $14.7-15.4 \%$, individual mineral substances from 2 to $14.1 \%$; various vitamins - from 2 to $106.2 \%$.
\end{abstract}

\section{Introduction}

Canned food is extremely popular with consumers, therefore, expanding their range for each enterprise of food and processing industry is a very urgent task.

Use of natural vegetal raw materials in the technology of production of canned meat promotes enrichment of products with functional ingredients, increases digestibility, allows to comply with physiological norms of healthy nutrition [1-8].

Canned dietary and functional products can have significant importance in the complex of measures to prevent detrimental effects of anthropogenic factors and adverse environmental conditions on human health. The purpose of this work was to develop balanced product formulation for healthy nutrition of different population groups, as well as to study the effect of joint and separate introduction of chicken meat, beans, pumpkin, and Brussels cabbage on the quality of original canned meat and vegetable chunks [7-15].

\section{Materials and methods}

Raw ingredients and 4 samples of original canned meat and vegetable based on chicken meat [16-20] are subjects of the research.

Employees of Agricultural Production and Processing Department of the Technology Faculty of Belgorod GAU studied the possibility of using pumpkin, beans, and Brussels cabbage as raw materials of plant origin in the production of canned meat and vegetable chunks. Natural meat of agricultural poultry on bones obtained from healthy agricultural poultry, passed veterinary and sanitary examination, admitted to industrial processing, and corresponding to safety indicators was used in the recipe.

Mass fraction of meat ingredient was 55.6\%, which meets the requirements of GOST standard R 54348-2011.

- fresh onion GOST standard 1723;

- fresh garden carrots GOST standard 1721;

- white salt GOST standard R 51574. The weight fraction of sodium chloride was $1.3 \%$, which meets the requirements of GOST R standard 54348-2011. Canned meat and poultry by-products. General specifications.

- pumpkin GOST standard 7975;

- beans GOST standard 34299;

- Brussels cabbage according to GOST standard 33851 .

Weight fraction of plant ingredients was $43.1 \%$. Optimal dosage of input vegetable raw materials is selected during preliminary model experiments.

The production of canned meat and vegetable products ensures waste-free production of poultry processing enterprises, saves time and consumer strength for cooking without preservatives, as well as to obtain a balanced solution for healthy nutrition with useful fibers, vitamins, and mineral elements.

The production of canned food samples based on chicken meat with the addition of vegetable raw materials was based on the traditional technology for the manufacture of canned meat and vegetable with the inclusion of individual elements of the original technology.

In the model formulation of sample No. 1, pumpkin was used as a vegetable component.

Pumpkin is a dietary food product and is rich in various biologically active substances. 
The pulp of this vegetable contains vitamin A (carotene), necessary for normal functioning of human visual system. It accumulates a lot of fiber, iron, vitamin $\mathrm{T}$ (carnitine) and is well absorbed by the body.

Beans were used as vegetable raw material as a part of recipe composition of sample No. 2.

Bean pods are a low-calorie source of important natural components: protein, complex carbohydrates, B vitamins, vitamin $\mathrm{K}, \mathrm{A}, \mathrm{C}$ and $\mathrm{E}$; mineral compounds. They are actively included in healthy and dietary menu.

Brussels cabbage acted as a vegetable component in the model formulation of sample No. 3 .

Brussels cabbage has more than 80 valuable nutrients. Vitamins A, C, K and B group, omega-3 fatty acids, macro- and trace elements: phosphorus, potassium, copper, calcium, and zinc, as well as numerous phytonutrients are among them.

All the above vegetables were used as a vegetable ingredient in formulation No. 3 .

Prototype's production of canned meat and vegetable products was carried out in the workshop for fruits and berries processing of Belgorod CPC, considering the provisions of regulatory basis in the field of healthy nutrition.

\section{Results}

Food and energy value, mineral and vitamin composition are defined in samples of canned food based on chicken meat and plant raw materials, as well as calculations of integral score of product samples.

Table 1 shows nutritional and energy value of manufactured product samples of all variants. Their mass fraction of valuable protein substances is from 10.7 to $11.2 \%$, including proteins of animal and plant origin.

All samples of canned products are low-calorie (lowcalorie) products, energy value of which was no more than $93.0 \mathrm{kcal}$, and fat content in them did not exceed $4.4 \%$.

Table 1. Food and energy value of samples of original canned food based on chicken meat with addition of vegetable raw materials.

\begin{tabular}{|c|c|c|c|c|}
\hline Indicator & $\begin{array}{c}\text { Sample №1 } \\
\text { (with } \\
\text { pumpkin) }\end{array}$ & $\begin{array}{c}\text { Sample №2 } \\
\text { (with } \\
\text { beans) }\end{array}$ & $\begin{array}{c}\text { Sample №3 } \\
\text { (with } \\
\text { Brussels } \\
\text { cabbage) }\end{array}$ & $\begin{array}{c}\text { Sample №4 } \\
\text { (vegetable } \\
\text { mix) }\end{array}$ \\
\hline \multicolumn{5}{|c|}{ Mass fraction, \% } \\
\hline protein & $10,8 \pm 0,53$ & $10,7 \pm 0,51$ & $11,2 \pm 0,62$ & $10,7 \pm 0,51$ \\
\hline fat & $4,4 \pm 0,32$ & $4,4 \pm 0,32$ & $4,4 \pm 0,32$ & $4,4 \pm 0,32$ \\
\hline $\begin{array}{c}\text { carbohyd } \\
\text { rates }\end{array}$ & $2,4 \pm 0,14$ & $2,2 \pm 0,13$ & $2,2 \pm 0,13$ & $2,3 \pm 0,13$ \\
\hline $\begin{array}{c}\text { sodium } \\
\text { chloride } \\
\text { (table } \\
\text { salt) }\end{array}$ & $1,3 \pm 0,07$ & $1,3 \pm 0,07$ & $1,3 \pm 0,07$ & $1,3 \pm 0,07$ \\
\hline $\begin{array}{c}\text { Energy } \\
\text { value } \\
100 \mathrm{~g}, \\
\text { kkal }\end{array}$ & $90,5 \pm 4,63$ & $90,9 \pm 4,68$ & $93,0 \pm 4,75$ & $91,4 \pm 4,71$ \\
\hline
\end{tabular}

The study of mineral composition of canned food samples based on chicken meat and plant raw materials showed that all versions of meat and vegetable products can be an additional source of macro and trace elements.
Samples of canned products were characterized by sodium content (Figure 1) from 564.4 to $565.3 \mathrm{mg} / 100 \mathrm{~g}$ of the product, which allows to satisfy daily demand of an adult in it by $14.1 \%$ or more.

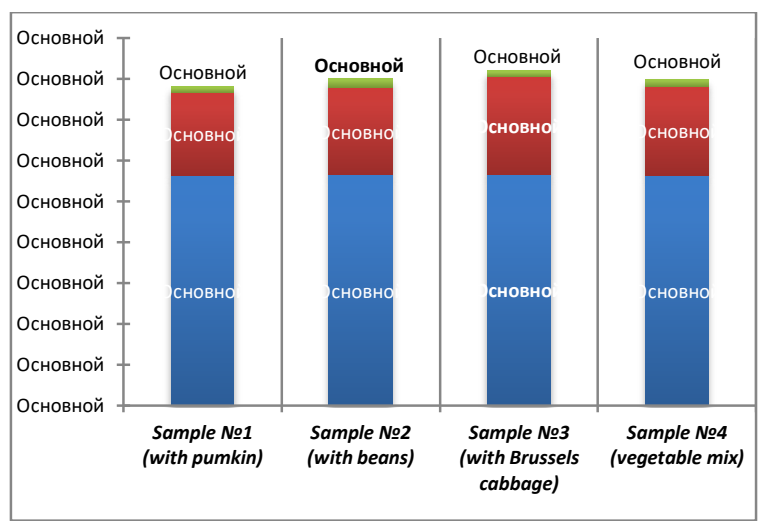

Fig. 1. Content of sodium (1), potassium (2) and calcium (3) in samples of original canned products based on chicken meat with the addition of vegetable raw materials ( $\mathrm{mg}$ )

Concentration of potassium in meat and vegetable products depending on the type of plant raw material component was $200.4-238.4 \mathrm{mg} / 100 \mathrm{~g}$ of the product, which makes it possible to provide an adult organism with this macroelement by $7.2-8.5 \%$ of daily demand for it.

The largest accumulation of sodium and potassium was obtained with the addition of Brussels cabbage (565.3 and $238.4 \mathrm{mg} / 100 \mathrm{~g}$ of the product).

In all canned food samples, calcium content varied from 14.2 to $22.1 \mathrm{mg} / 100 \mathrm{~g}$ of the product. It is about $2.0 \%$ of daily adult consumption rate. The highest calcium concentration was observed when using vegetable beans $(22.1 \mathrm{mg} / 100 \mathrm{~g}$ of the product).

Magnesium accumulation (Figure 2) in different canned products ranged from 16.4 to $21.5 \mathrm{mg} / 100 \mathrm{~g}$ of the product and was $4.1-5.4 \%$ of an adult recommended daily standard.

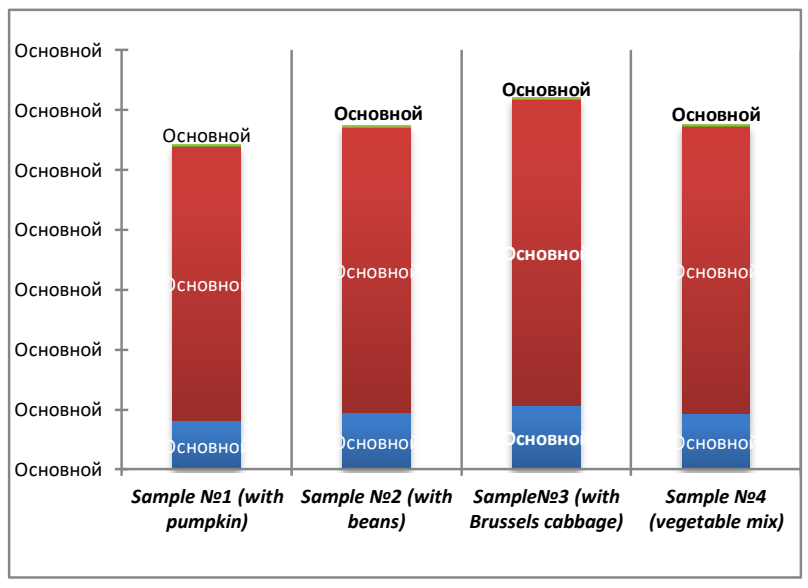

Fig. 2. Content of magnesium (1), phosphorus (2) and iron (3) in samples of original canned products based on chicken meat with the addition of vegetable raw materials (mg)

Samples of canned products were characterized by phosphorus content of 91.6 to $101.9 \mathrm{mg} / 100 \mathrm{~g}$ of the 
product, which made it possible to satisfy daily demand of an adult in it by $7.6 \%$ or more.

Concentration of iron in samples of meat and vegetable products depending on the type of plant raw material component was about $0.7 \mathrm{mg} / 100 \mathrm{~g}$ of the product, which allows this element to provide an adult body with up to $5.0 \%$ of a daily need for it.

The largest accumulation of magnesium and phosphorus was obtained with the addition of Brussels cabbage 21.5 and $101.9 \mathrm{mg} / 100 \mathrm{~g}$ of the product.

The characterization of vitamin composition of the product is an important indicator of its nutritional value. This group of compounds and substances is of great importance to human body as a catalyst and bioregulator of metabolic processes. Introduction of plant raw materials rich in vitamins into canned products made it possible to significantly affect their concentration in the product (Table 2).

Table 2. Vitamin composition of samples of original canned products based on chicken meat and vegetable raw materials.

\begin{tabular}{|c|c|c|c|c|}
\hline Vitamins, mg & $\begin{array}{c}\text { Sample } \\
\text { №1 } \\
\text { (with } \\
\text { pumpkin) }\end{array}$ & $\begin{array}{c}\text { Sample } \\
\text { №2 } \\
\text { (with } \\
\text { beans) }\end{array}$ & $\begin{array}{c}\text { Sample №3 } \\
\text { (with } \\
\text { Brussel } \\
\text { cabbage) }\end{array}$ & $\begin{array}{c}\text { Sample №4 } \\
\text { (vegetable } \\
\text { mix) }\end{array}$ \\
\hline Vitamin C & 1,4 & 2,4 & 9,6 & 4,2 \\
\hline Tiamin (B1) & 0,1 & 0,1 & 0,1 & 0,1 \\
\hline $\begin{array}{c}\text { Riboflavin } \\
\text { (B2) }\end{array}$ & 0,1 & 0,1 & 0,1 & 0,1 \\
\hline Niacin (PP) & 5,2 & 17,0 & 14,0 & 11,4 \\
\hline $\begin{array}{c}\text { Vitamin A, } \\
\text { mkg }\end{array}$ & 240,0 & 199,6 & 201,8 & 216,4 \\
\hline
\end{tabular}

Samples of canned products have vitamin C (from 2.0 to 1.4 to $9.6 \mathrm{mg} / 100 \mathrm{~g}$ of the product), which makes it possible to satisfy an adult daily demand in it by 2.0 $13.7 \%$. The greatest accumulation of useful elements was obtained with the addition of Brussels cabbage (9.6 $\mathrm{mg} / 100 \mathrm{~g}$ of the product).

The concentration of thiamine and riboflavin in samples with meat and vegetables was $0.1 \mathrm{mg} / 100 \mathrm{~g}$ of the product, which makes it possible to provide an adult human body with this macroelement by 4.8 and $5.2 \%$, respectively, of a daily need for it.

The accumulation of niacin in canned products of different variants ranged from 5.2 to $17.0 \mathrm{mg} / 100 \mathrm{~g}$ of the product and amounted to $32.5-106.2 \%$ of the recommended daily norm for an adult. The highest concentration of niacin was otained when adding beans (17.0 $\mathrm{mg} / 100 \mathrm{~g}$ of the product).

Samples of canned products have vitamin A (from 201.8 to $240.0 \mathrm{mgk} / 100 \mathrm{~g}$ of the product), which allows to satisfy an adult daily demand for it on $22.2-26.7 \%$.

The largest accumulation of vitamin A was obtained with the addition of pumpkin - $240 \mathrm{mgk} / 100 \mathrm{~g}$ of the product.

According to safety indicators (content of toxic elements and pesticides) and microbiological criteria, canned products based on chicken meat and vegetables met the requirements of TR TC 021/2011.

Thus, samples of original canned products based on chicken meat and vegetables according to nutrient composition meet physiological needs of an adult population.

\section{Discussion}

Finished sterile canned products based on chicken meat and vegetables area combined product of "solyanka" type. They are recommended for use in heated form as a second dish or as a cold snack.

Evaluation of organoleptic indices of all samples of canned products was also done (Figure 3 ).

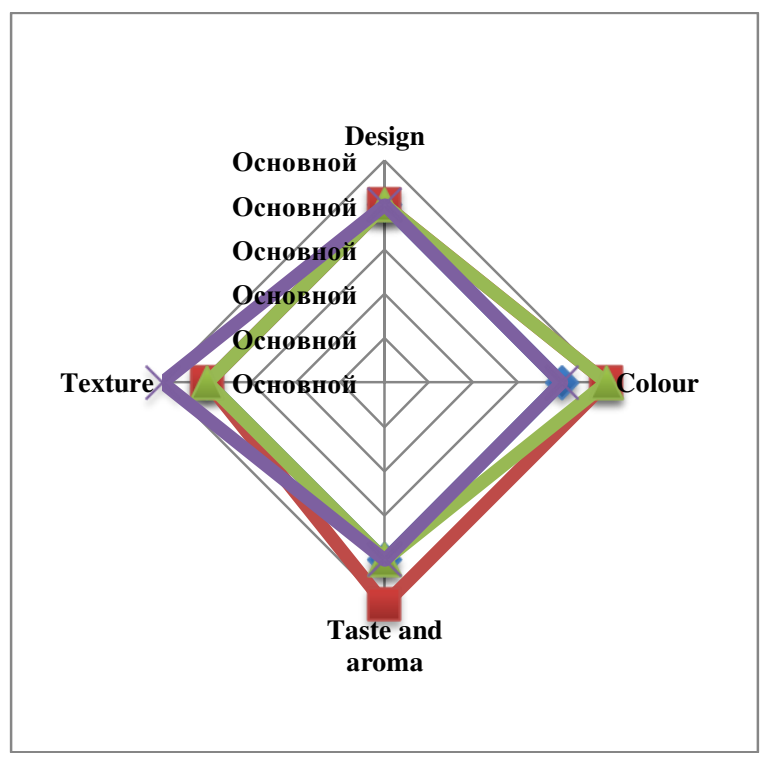

Fig. 3. Organoleptic evaluation of meat and vegetable canned products depending on the type of vegetables

Tasting analysis showed that developed original canned products based on chicken meat and vegetables have good consumer properties.

\section{Conclusion}

Developed canned products are an additional source of vitamins, including vitamin $\mathrm{C}$, thiamine, riboflavin, niacin, vitamin $\mathrm{A}$; and minerals, including sodium, potassium, calcium, magnesium, phosphorus, and iron.

They have low-calorie content (no more than 93.0 kcal). According to the level of accumulation of niacin and vitamin A, samples of meat and vegetable canned products have a functional orientation (GOST R 52349).

Developed canned products based on chicken meat and vegetables (pumpkin, beans and Brussels cabbage) have quite good consumer properties and can satisfy preferences of the population adhering to the principles of healthy nutrition.

\section{References}

1. F. Smolnikova, B. Abilmazhinova, B. Sakhayev [et al.] 2019 Improving the technology of functional meat pates from different types of raw meat products 
International Journal of Pharmaceutical Research Vol. 11 704-708.

2. O. Cherednichenko and L. Bal-Prylypko 2020 Rationale and economic feasibility of improving the technology of longterm storage of meat products IOP Conf. Ser.: Earth Environ. Sci. 548022053

3. M. M. Danyliv, O. A. Vasilenko, O. N. Ozhereleva, N. M. Derkanosova 2018 Production Engineering of the Low Fat Meat Products Advances in Engineering Research, Tyumen: Atlantis Press, 129-135.

4. I. A. Chernukha 2020 Randomised controlled trial of innovative specialised meat product for patients with cardiovascular and metabolic disorders Potravinarstvo Slovak Journal of Food Sciences. Vol. 14 458-464. DOI: https://doi.org/10.5219/1298

5. A. B. Lisitsyn, I. M. Chernukha, M. A. Nikitina 2020 Russian methodology for designing multicomponent foods in retrospect Foods and Raw Materials Vol. 8 2-11. DOI: 10.21603/2308-4057-2020-1-2-11.

6. N. L. Vostrikova, A. V. Zherdev, E. A. Zvereva, I. M. Chernukha 2020 Quality and safety of meat products in Russia: Results of monitoring samples from manufacturers and evaluation of analytical methods Current Research in Nutrition and Food $\begin{array}{lllll}\text { Science. } & \text { Vol. } 8 & \text { P. } & 41-47 . & \text { DOI }\end{array}$ : http://dx.doi.org/10.12944/CRNFSJ.8.1.04.

7. I. M. Chernukha, L. .I Kovalev, N. G. Mashentseva, M. A. Kovaleva, N. L. Vostrikova 2019 Detection of protein aggregation markers in raw meat and finished products Foods and Raw Materials. Vol.7 118-123. DOI: 10.21603/2308-4057-2019-1-118-123.

8. M. A. Nikitina, I. M. Chernukha, D. E. Nurmukhanbetova 2019 Principal approaches to design and optimization of a diet for targeted consumer groups News of the National Academy of Sciences of the Republic of Kazakhstan, Series of Geology and Technical Sciences. Vol.1 231-241. DOI: $10.32014 / 2019.2518-170 X .28$.

9. N. L. Vostrikova, I. M. Chernukha 2018 Identification of tissue-specific proteins and peptides forming innovative meat products corrective properties to confirm authenticity of meat raw Foods and Raw Materials. Vol. 6 201-209. DOI 10.21603/2308-4057-2018-1-201-209.

10. S. E. Shukesheva, Y. M. Uzakov, I. M. Chernukha, Z. S. Nabiyeva, A. B. Nurtaeva 2018 Research to improve the quality of food products News of the National Academy of Sciences of the Republic of Kazakhstan, Series of Geology and Technical Sciences. Vol.3 37-45.

11. V. A. Bagirov, S. Y. Zaitsev, I. M. Chernukha, N. A. Zinovieva 2016 Comparative study of the fatty acid composition of lipids in the raw meat samples obtained from hybrid sheep 41st FEBS Congress on Molecular and Systems Biology for a Better Life: Kusadasi, TURKEY. Vol.283 363-363.

12. A. N. Fedosova, M. V. Kaledina 2017 New approaches to creating functional products for a closed milk-polysaccharide system Foods and Raw
Materials. Vol. 5. 44-53. DOI 10.21603/2308-40572017-2-44-53.

13. Galstyan A. G., Aksenova L. M., Lisitsyn A. B., Oganesyants L. A., Petrov A. N. 2019 Modern approaches to storage and effective processingof agricultural products for obtaining high quality food products Herald of the Russian Academy of Sciences. 211-213.

14. Konnov A. V., Belozerov G. A., Dibirasulaev M. A. 2019 Time domain numerical simulation of convection heating of a muscle tissue with phase transition Moscow University Physics Bulletin. 302307.

15. Vorobyeva V., Vorobyeva I., Kochetkova A., Mazo V., Zorin S., Sharafetdinov Kh 2020 Specialized hypocholesterolemic foods: ingredients, technology, effects Foods and Raw Materials. 20-29.

16. Koshchaev I., Mezinova K., Ryadinskaya A., Tatyanicheva O. and Ordina N. 2020 Various sources of methionine in broiler chicken rations E3S Web Conf. Innovative Technologies in Science and Education (ITSE-2020) 210 1-8

17. Koshchaev I., Mezinova K., Ryadinskaya A., Sorokina N. and Chuev S. 2020 Identification of cases of pododermatitis in broiler chickens when feeding a probiotic feed additive E3S Web Conf. Innovative Technologies in Science and Education 210 1-8 (ITSE-2020)

18. I. A. Koshchaev, K. V. Mezinova and A. A. Ryadinskaya 2021 Effect of probiotic cultures of the Bacillus amyloliquefaciens strain on the livability of broiler chickens IOP Conf. Series: Earth and Environmental Science (SUSTAINABLE AND INNOVATIVE DEVELOPMENT IN THE DIGITAL AGE) 650 1-6

19. Koschayev I., Boiko I., Kornienko S., Tatiyanicheva O., Sein O., Zdanovich S. and Popova O. 2019 Feeding Efficiency of Dry Beet Pulp to Broiler Chickens Advances in Biological Sciences Research 1st International Symposium Innovations in Life Sciences (ISILS 2019) 7 167-170

20. I. A. Koshchaev, K. V. Mezinova, N. N. Sorokina, A. A. Ryadinskaya, N. B. Ordina and S. A. Chuev 2021 Body weight dynamics of broiler chickens by feeding probiotic preparation IOP Conf. Series: Earth and Environmental Science (ESDCA 2021) 723 1-6 